\title{
LEITURA DE IMAGENS DA MÍDIA E EDUCAÇÃO AMBIENTAL: CONTRIBUIÇÕES PARA A FORMAÇÃO DE PROFESSORES
}

\author{
Rosana Louro Ferreira Silva*
}

RESUMO: Esta investigação, de caráter qualitativo, teve como objeto de estudo as imagens de capas de revistas de grande circulação, associadas à questão ambiental. Os objetivos principais foram: identificar as concepções da questão ambiental presentes nas imagens e verificar de que forma os professores em formação interpretam, ressignificam e se apropriam das mensagens expressas nessas imagens. A análise das imagens identificou uma preponderância da concepção pragmática e antropocêntrica da questão ambiental. O trabalho de leitura de imagens em cursos de formação de professores orientou-se pela perspectiva crítica da educação ambiental. A partir dos resultados, argumentamos que o processo interpretativo de imagens na formação inicial e continuada, bem como na escola, poderia possibilitar uma ferramenta a mais na construção da cidadania, formando observadores menos ingênuos e mais críticos diante das imagens com que se deparam na vida cotidiana, em especial as associadas à questão ambiental.

Palavras-chave: Imagens; Questão Ambiental, Formação de Professores.

\section{THE ANALYSES OF MEDIA IMAGES AND ENVIRONMENTAL EDUCATION:} \section{A CONTRIBUTION TO TEACHERS' TRAINING}

ABSTRACT: This qualitative research was aimed at studying the images regarding environmental issues on the front cover of popular magazines. The main objectives were to identify the conceptions of environmental issues portrayed in the images and understand how teachers under training interpreted, revalued and kept the messages therein. The analysis of the images led to a dominantly pragmatic and anthropocentric conception of the environmental issue. The images interpretation in teacher training courses was performed from a critical point of view of the environmental education. Based on these results, we believe that the interpretative process of the images in graduation and further education courses, as well as at elementary schools, could provide another tool to contribute to the achievement of citizenship, developing less naive and more critical observers in the face the images they are exposed to throughout their daily lives, especially images concerning environmental issues.

Keywords: Images; Environmental Issues; Teacher Training Courses.

\footnotetext{
* Professora Adjunta do Centro de Ciências Naturais e Humanas da Universidade Federal do ABC (UFABC). E-mail:
} rosana.ferreira@ufabc.edu.br 


\section{Introdução}

Os meios de comunicação de massa (televisão, jornais, revistas e, mais recentemente, a internet) representam importante papel na produção e na difusão de informações a respeito de diversos assuntos da atualidade, estando entre eles a questão ambiental. Essas informações são veiculadas de forma escrita, oral, visual e audiovisual. Dessa forma, assumem papel importante na veiculação dessas informações as imagens escolhidas e/ou produzidas para representar a questão.

A partir de fevereiro de 2007, após a publicação do relatório do Painel Intergovernamental de Mudanças Climáticas - IPCC ${ }^{1}$, contendo previsões a respeito do problema do aquecimento global, a questão ambiental ganha destaque poucas vezes visto nos meios de comunicação. A mídia impressa, por exemplo, diversas vezes trouxe a problemática ambiental como reportagem de capa, ou seja, onde a revista ou o jornal apostam a venda do exemplar do dia, da semana ou do mês.

A continuidade da publicação de reportagens sobre a temática revela que o assunto tem despertado grande interesse da população em geral. Pesquisa realizada sob responsabilidade do Ministério da Ciência e Tecnologia sobre Percepção Pública da Ciência (BRASIL, 2007) revelou que o tema Meio Ambiente só não foi mais citado do que Medicina e Saúde, estando à frente na lista de interesse entre os entrevistados, em relação a assuntos como política, arte e cultura, ciência e tecnologia, religião, entre outros.

Nesse contexto da comunicação midiática, entendemos que a imagem assume papel fundamental. Para aprofundar nossa análise, passamos a adquirir exemplares de revistas que traziam destaque de capa para a questão ambiental, na busca de tentar entender como o fenômeno estava sendo representado pela mídia impressa.

Para Reigota (1999, p. 109), os meios de comunicação são “espaços que originam e difundem representações sociais através de fragmentos das diversas interpretações e imagens sobre, entre outros, os problemas ambientais". Nesse sentido, considera que "os profissionais envolvidos com a educação ambiental devem procurar discutir o que esses meios representam e divulgam em sociedades com diferentes níveis de escolaridade" (REIGOTA, 1999, p. 109). A partir desse pressuposto e da teoria das representações sociais, Reigota (1999) apresentou uma proposta peda- 
gógica de educação ambiental no contexto da globalização, em um processo de interpretação e dialogicidade a partir de imagens coletadas pelo autor em diferentes "espaços" mundiais.

Não temos por hábito analisar as imagens presentes no nosso cotidiano. Geralmente elas são "consumidas" de forma rápida e sem reflexão. No entanto, partimos do pressuposto de que essas imagens, mesmo que inconscientemente, acabam por influenciar nosso entendimento e nossas concepções sobre a questão ambiental.

Analisando as questões da indústria cultural e sua relação com a educação, a mídia acaba por induzir a formação da opinião em vários âmbitos da vida, entre as quais incluo a questão ambiental. Loureiro e Fonte (2003) destacam a padronização do juízo ético e estético dos indivíduos pelos meios de comunicação de massa, de acordo com a lógica do sistema, ou seja, a lógica do mercado. Dessa forma, "a educação não pode ignorar as representações culturais que contribuem para o processo de formação das individualidades. Deve-se cada vez mais questionar e problematizar as verdades estabelecidas com base nos produtos imagéticos" (LOUREIRO; FONTE, 2003, p. 85). Para tanto, os autores indicam a necessidade de uma "educação estética crítico-emancipatória" (OLIVEIRA et al., 2001 apud LOUREIRO; FONTE, 2003).

Nossa proposta se baseia em uma educação ambiental crítica, acreditando que o processo de discussão de imagens advindas de diferentes fontes pode contribuir para essa perspectiva. Loureiro (2004) aponta que a atribuição central de uma educação ambiental na perspectiva histórica e crítica "é fazer com que visões ecológicas de mundo sejam discutidas, compreendidas problematizadas e incorporadas em um processo integrador, sem a imposição de uma única concepção, vista como verdadeira" (LOUREIRO, 2004, p. 39).

Dessa forma, o problema que motivou e orientou esta pesquisa pode ser expresso na seguinte pergunta: Que imagens a mídia impressa tem produzido recentemente a respeito/a partir da problemática ambiental e de que forma a análise dessas imagens na formação docente pode ser utilizada na perspectiva da educação ambiental crítica?

Partindo dessa pergunta central, os objetivos principais que nortearam a investigação foram: identificar as concepções da questão ambiental presentes nas imagens das capas de revistas de grande circulação publicadas no período que vai do segundo semestre de 2006 ao pri- 
meiro semestre de 2008; verificar de que forma os professores em formação interpretam, ressignificam e se apropriam das mensagens transmitidas pelas imagens; e refletir sobre as possibilidades de as imagens cotidianas serem utilizadas como objetos de reflexão dialógica e crítica na formação de professores em educação ambiental.

\section{A questão ambiental na mídia}

Uma das principais referências para uma Educação Ambiental na perspectiva crítica, o Tratado de Educação Ambiental para Sociedades Sustentáveis e de Responsabilidade Global, propõe, na diretriz n. 15 do plano de ação, "garantir que os meios de comunicação se transformem em instrumentos educacionais para a preservação e conservação de recursos naturais...".

$\mathrm{O}$ artigo $3^{\circ}$ da Política Nacional de Educação Ambiental - Lei n. 9795/99 - dispõe que "como parte de um processo educativo mais amplo, todos tem direito à educação ambiental, incumbindo aos meios de comunicação de massa, colaborar de maneira ativa e permanente na disseminação de informações e práticas educativas sobre o meio ambiente...”.

Reigota (1999) analisando imagens de desenhos, caricaturas, capas de livros, publicidade e outros produtos imagéticos sobre a questão ambiental, na perspectiva da teoria das representações sociais, considera que elas originam, difundem e legitimam representações, trazendo, de forma implícita ou explícita, o "potente capital simbólico das instituições, grupos e pessoas que as produzem e divulgam” (REIGOTA, 1999, p. 93).

Não obstante o reconhecimento da importância dos meios de comunicação para o caráter educativo sobre a questão ambiental, pesquisas têm apontado a fragilidade com que essas mensagens apresentam a problemática ambiental (RAMOS, 2002; ANDRADE, 2003; GUIDO, 2006; LUCKMAN, 2007; FLORENTINO, 2007; SILVA, 2007), com aspectos que priorizam a espetacularização e o catastrofismo e com superficialidade das informações.

Ao analisar as imagens de educação ambiental do programa Repórter Eco, Guido (2006) ressalta que "a veiculação de belas paisagens da natureza vêm, na sua maioria, sem a presença do homem, reforçando a idéia de que a paisagem natural deve ser intocada" (GUIDO, 2006, p. 8). 
Entendemos que a apresentação de visões como essa contribuem para a consolidação de concepções naturalistas de ambiente.

Ramos (2002), ao estudar a propaganda das ONGs ambientais na televisão, observou que

[...] os filmes não apresentaram elementos capazes de estimular o receptor a tomar uma atitude, prejudicando a implementação da estratégia de apelo em sua forma integral, visto que não há um estímulo para canalizar o sentimento inicialmente gerado e transformá-lo em uma ação efetiva de enfrentamento do problema. (RAMOS, 2002, p. 205)

Buscando elucidar as formas pelas quais o debate ambiental adentra ao mundo do espetáculo, Andrade (2003) analisou episódios do programa Amaral Neto, o Repórter, da década de 1970, e do programa Globo Ecologia. Esse autor ressalta, nos programas analisados, que as belas imagens e atores conhecidos propiciam mais legitimidade do que participação comunitária e proximidade social, sendo que o relacionamento com a problemática ambiental "passa a ser mediado por aspectos mais próximos às formas de criação e seleção no campo ficcional, e cada vez menos por posições ideológicas e ideários coletivos" (ANDRADE, 2003, p. 229).

Florentino (2007), ao realizar uma análise sobre o discurso e as imagens de um programa televisivo semanal, em um episódio voltado à questão ambiental, destaca que

[...] é importante valorizar a capacidade do "distanciamento" tão necessária para a percepção do que está por trás das aparências, do que é mitificado e apresentado como verdade indiscutível. Na era da comunicação e da sociedade de risco, em que os problemas são globais e os discursos se entrelaçam de forma a obscurecer fronteiras claramente definidas, a escola deve repensar o seu papel (FLORENTINO, 2007, p. 4).

Não obstante a importância desses trabalhos de análise, tornamse necessárias pesquisas que avaliem como essas mensagens são recebidas. Importantes contribuições nesse sentido são oferecidas por Reigota (1999) e Luckman (2007). Esta autora apresenta os resultados de um trabalho que buscava identificar processos de recepção de estudantes de jornalismo e de pedagogia de dois artigos de revista sobre o aquecimento global. A autora observou que ceticismo, impotência e vontade de contri- 
buir são sentimentos comuns apresentados pelos estudantes após análise de textos que geralmente fazem previsões catastróficas do futuro do planeta. Ela alerta que o ceticismo e a impotência ainda aparecem como empecilho para a participação e a ação, muito mais do que uma consciência crítica baseada nos fatos. No entanto, a autora destaca que o trabalho com os textos de revista também propiciaram uma discussão crítica sobre os problemas ambientais, o que a faz defender a importância de que pesquisadores, tanto da educação quanto da comunicação, desenvolvam pesquisas que "considerem tanto as representações de quem produz o discurso da mídia como do receptor" (LUCKMAN, 2007, p. 14). Neste trabalho, pretendemos apresentar contribuições nesse sentido.

\section{Pesquisas sobre análise e interpretação de imagens}

Diferentes autores têm trazido contribuições importantes para a interpretação e a utilização de imagens, ressaltando a necessidade de se educar para a leitura desses símbolos visuais (REIGOTA, 1999; MARTINS; GOUVÊA, 2003; LOUREIRO; FONTE, 2003; BRUZZO, 2004; COSTA, 2005, SILVA, 2006), entendendo "leitura" como processo de atribuição de sentidos por meio de uma interpretação consciente. Parte-se do pressuposto de que as imagens não possuem significado imediato e transparente, como pode parecer, e que sua leitura é uma atividade complexa, situada e profundamente influenciada por princípios que organizam possibilidades de representação, significação e produção de sentidos em dada cultura (MARTINS; GOUVÊA, 2003).

Costa (2005) problematiza o fato de a imagem se tornar elemento secundário na educação a partir do momento que a criança se alfabetiza, entendendo isso como um paradoxo, uma vez que a imagem é universal e tão importante para a cultura humana. Apresenta, para isso, a hipótese de que a imagem é considerada como pouco precisa, ambígua ou excessivamente particular, parecendo pouco ligada à racionalidade. Para essa autora, o processo de interpretação de uma imagem é uma busca de explicação para os sentimentos que ela nos desperta e, por isso, também é um trabalho de autoconhecimento.

Tendo em vista a complexidade da questão ambiental, as imagens associadas ao discurso ecológico moderno não podem ser desconsi- 
deradas nos significados que alunos, professores e o público em geral atribuem à temática ambiental.

Utilizando elementos da análise do discurso, Silva (2006) apresenta uma reflexão sobre a relação entre imagem e realidade, argumentando que objetos simbólicos como as imagens não carregam sentidos em si, "mas são elementos de um processo mais amplo e complexo de produção de sentidos, dos quais fazem parte também o sujeito, a situação imediata e o contexto sociocultural mais amplo" (SILVA, 2006, p.72). Esse autor traz a proposta de analisarmos imagens no ensino de ciências comparando seus graus de iconicidade, ou seja, partir da imagem que guarda mais elementos do objeto representado (embora nunca representando a realidade, sendo sempre uma construção) para aquela mais abstrata.

Para autores como Loureiro e Fonte (2003), para uma educação estética, entendida como uma "educação da sensibilidade", o sentido compreende tanto a capacidade de receber sensações quanto a consciência que se tem delas, sendo que essa consciência não é só biológica, mas se forma historicamente. Para os autores, "a linguagem imagética ganha espaço na forma de o indivíduo perceber a realidade do mundo contemporâneo e, com o crescente desenvolvimento dos meios imagético- eletrônicos, a vida aparecer como algo para ser visto" (LOUREIRO; FONTE, 2003, p. 80).

Bruzzo (2004), em pesquisa na qual investiga as representações de seres vivos ao longo da história, ressalta a possibilidade de as imagens fornecerem uma compreensão singular do mundo natural e que "a reflexão sobre natureza requer o reconhecimento das dificuldades em expressar uma percepção objetiva do mundo natural" (BRUZZO, 2004, p. 1361).

Para Costa (2005), assim como toda e qualquer atividade na escola, o uso da linguagem visual, tendo como ferramenta a interpretação das imagens, exige planejamento e aprendizado, em busca de um entendimento mais afetivo de mundo e de uma comunicação mais abrangente e inclusiva, destacando que “...exatamente pelo caráter emotivo, ambíguo e afetivo das imagens, pelo fato delas nos tomarem desde o primeiro olhar e por poderem nos enganar, o seu uso na educação envolve informação, conhecimento, preparo e gestão ... (COSTA, 2005, p. 37). Acreditando em uma educação ambiental que envolve, além de aspectos puramente racionais, também componentes ligados a afetividade, é que entendemos que 
processos que trabalhem aspectos perceptivos relacionados à temática ambiental também são importantes para a construção do envolvimento e da participação ativa nos conflitos resultantes da relação do ser humano com o meio ambiente.

\section{0 processo de análise das imagens de capa sobre a questão ambiental}

Bardin (1977, p. 35) destaca que "as imagens também podem ser analisadas como conteúdo”. De acordo com a autora, a análise de conteúdo tem por objetivo a manipulação de mensagens, buscando a inferência de conhecimentos relativos às condições de produção/recepção dessas mensagens. Entre os instrumentos propostos nessa metodologia foi utilizada a análise categorial, utilizando as categorias de concepções propostas em Silva (2007) para materiais audiovisuais de educação ambiental, entendendo que as mesmas, adaptadas ao material a ser analisado (Quadro 1), propiciavam uma compreensão geral das concepções mais divulgadas pela imagens selecionadas sobre a problemática.

Quadro 1 - Caracterização das concepções de questão ambiental, adaptadas de Silva (2007)

\begin{tabular}{|c|c|c|}
\hline Conservadora & Pragmática & Crítica \\
\hline $\begin{array}{l}\text { - padrões de comportamento em } \\
\text { perspectiva maniqueísta; } \\
\text { - dicotomia ser humano - } \\
\text { mundo natural; } \\
\text { - retorno à natureza intocada; } \\
\text { - Ser humano faz parte da natureza } \\
\text { em sua dimensão biológica: } \\
\text { reducionismo biológico; } \\
\text { - natureza contemplativa; } \\
\text { - prioridade aos aspectos } \\
\text { naturais do meio. }\end{array}$ & $\begin{array}{c}\text { • antropocentrismo; } \\
\text { • lei de ação e reação } \\
\text { (natureza vingativa); } \\
\text { • solução depende do querer fazer, } \\
\text { segundo o qual todos são igualmente } \\
\text { responsáveis; } \\
\text { • ênfase nos comportamentos } \\
\text { individuais: modelos a serem seguidos; } \\
\text { • cidadão é o consumidor; } \\
\text { • perspectiva fatalista - precisa } \\
\text { proteger o ambiente para poder sobreviver. }\end{array}$ & $\begin{array}{l}\text { • Ser humano pertence à teia de } \\
\text { relações sociais, naturais e culturais e } \\
\text { vive em interação; } \\
\text { • distribuição desigual dos } \\
\text { riscos ambientais; } \\
\text { • relação com o meio é } \\
\text { historicamente determinada; } \\
\text { • responsabilidades das diferentes } \\
\text { instâncias (sociedade civil, governo, } \\
\text { ONGs); } \\
\text { • ênfase na participação coletiva. }\end{array}$ \\
\hline
\end{tabular}

Foi realizada uma análise de conteúdo de nove imagens de capa de revistas de circulação nacional (apresentadas no Anexo 1) e descritas a seguir:

- Revista Época: três edições recentes trouxeram a questão ambiental como reportagem de capa:

1) Edição n. 439, de 16 de outubro de 2006: capa de fundo verde com a foto de uma família vestida com roupas verdes composta por um 
homem, uma mulher e uma criança. Acompanha a imagem da família um cachorro, este também portando um lenço verde. A frase que acompanha a capa é "Pense verde: o que você pode fazer para salvar o planeta";

2) Edição n. 455, de 5 de fevereiro de 2007: capa de fundo preto com dizeres em cinza "O mundo vai acabar?". A figura do globo terrestre, que tradicionalmente substitui a letra $\mathrm{O}$ do nome da revista, aparece como se estivesse derretendo. Complementa a frase de alerta, que diz "O mais importante relatório sobre o aquecimento global mostra que a situação é pior do que imaginávamos";

3) Edição n. $515^{3}$, de 31 de março de 2008: capa de fundo branco tem a imagem de uma lata com a tampa aberta como por um abridor e, dentro, aparecem fotos de árvores que lembram uma floresta. $\mathrm{Na}$ lata, está representada a figura do globo terrestre também como se estivesse derretendo. A frase que acompanha é "Compre verde: como suas compras domésticas podem ajudar a salvar a Terra";

- Revista Veja: também tem três edições recentes nas quais a questão ambiental é reportagem de capa:

1) Edição n. 1989, de 30 de dezembro de 2006: na capa de fundo branco, aparece a figura de um despertador, tendo o globo terrestre representado dentro dele. A frase que acompanha é "Alerta global: 7 megassoluções para o megaproblema ambiental";

2) Edição n. 2031, de 24 de outubro de 2007: capa de fundo branco contém a foto de uma mulher segurando uma bicicleta. No cestinho da bicicleta está um bebê, aparentando ser do sexo feminino, segurando um balão com a figura do planeta. A frase que acompanha é "Salvar a Terra: como essa idéia triunfou - Militância Ecológica: dos 'verdes' aos radicais do 'planeta sem gente' - O que pensam os poucos (e honestos) cientistas céticos". Nota-se que são indicadas setas para vários aspectos da imagem que indicam: Consciência ambiental (cabeça da mulher), Camiseta de fibra reciclada, Cantil para evitar garrafas PET, calça de algodão orgânico feita a mão, sandálias com sola de pneu reciclado, bicicleta (zero de $\mathrm{CO}^{2}$ ), alimentos orgânicos, fralda de pano, filho único...;

3) Edição n. 2003, de 11 de abril de 2007: capa com fundo branco com foto de família de ursos polares. A frase que acompanha é "O alerta dos pólos: VEJA foi ao ártico e à Antártica e encontrou cientistas alarmados com o ritmo do derretimento do gelo polar"; 
- Revista Nova Escola n. 202, de maio de 2007: A capa, de fundo verde escuro, tem a foto de um par de mãos adultas apoiando um par de mãos de criança e, nas mãos da criança, um pouco de terra e uma mudinha de planta. A frase que acompanha é "5 experiências de sucesso na Educação ambiental: dicas imperdíveis para você ajudar seus alunos a garantir o futuro do planeta";

- Revista Scientific American Brasil n. 19, Edição Especial publicada no mês de junho de 2007: A capa é composta por um desenho de chão de terra seca, com pinheiros ao fundo, e, mais ao fundo, sombras de fábricas com fumaça saindo pela chaminé e um céu de cor amarronzada. Três pessoas de costas, um homem segurando um cartaz de céu azul com uma nuvem branca, uma mulher segurando uma muda de pinheiro e outro homem que observa a cena. A frase que acompanha é "Como deter o aquecimento global: o que governos, empresas e cidadãos podem fazer";

- Revista Carta na Escola n. 12, de dezembro de 2006: Foto de um garoto indiano negro, sorrindo, mergulhado em um rio, entre flores e lixo. A frase que acompanha a capa é "Meio Ambiente: Uma conta de 7 trilhões: Relatório do governo britânico estima o tamanho do prejuízo provocado pelo aquecimento global".

Todas as revistas analisadas têm público escolarizado que gosta de se manter informado sobre os principais assuntos da atualidade e usa a mídia impressa com essa finalidade. No entanto, as revistas Nova Escola e Carta na Escola são direcionadas ao público de professores de ensino fundamental e médio. Já a Scientific American Brasil tem público formado, em sua maioria, por professores do ensino básico e superior e estudantes de nível superior e/ou pós-graduação.

A análise de conteúdo das capas das revistas permitiu-nos agrupá-las por semelhança de concepção da questão ambiental, tendo a concepção pragmática prevalecido.

Entendemos como ligada a uma concepção conservadora a imagem da família de ursos polares com expressões que revelam fragilidade, destacando-se no texto "as primeiras vítimas", sendo priorizados aspectos naturais em perspectiva fatalista.

As revistas Época edição n. 455 e Veja Edição n. 2003 trazem, em suas imagens e textos de capa, a noção de catástrofe ambiental expressa pela cor preta (Época) e pela figura do despertador ( $V_{e j a}$ ), representando que "temos pouco tempo" ou "vamos preservar enquanto há tempo". 
Para diversos autores, entre eles Grün (1996) e Carvalho (2007), essa perspectiva fatalista pouco contribui para a participação e para influenciar positivamente as atitudes individuais e coletivas.

As revistas Época 439 e 515 e a Veja n. 2031 apresentam concepção pragmática da questão ambiental. Nas três revistas, há apelo à "salvação do planeta", a partir da proposta de comportamentos ambientalmente corretos. As capas de Época 439 e Veja 2031 são bem semelhantes. Apresentam fotos de pessoas aparentando serem de classe social média/alta e instruídas, o que é possível inferir pelas roupas (verdes e modernas) e "posturas ecológicas" propagadas como "comportamentos ambientalmente corretos", como ter filho único. Na Veja, são destacados por textos comportamentos como andar de bicicleta, consumir apenas alimentos orgânicos e usar calçados de sola de pneu, além da indicação para a cabeça apontada como "consciência ecológica".

Com foco imagético não mais nos "consumidores", mas nos "produtos" a serem consumidos, na Época 515, o indivíduo deve continuar comprando, só que, agora, os "produtos sustentáveis", oferecidos por lojas, fábricas e supermercados que "neutralizam suas emissões de gás carbônico", que vêm em "embalagem reciclada", e fazendo-se empréstimos em "bancos ecológicos". Sobre esse aspecto do consumo, ressalta-se que a publicidade interna da maioria dessas revistas cuja questão ambiental é reportagem de capa é voltada aos produtos e às empresas sustentáveis. Embora entendamos que a sustentabilidade é um importante aspecto a ser pensado pelas empresas da atualidade, o incentivo ao consumo cada vez maior e descomprometido com a realidade social parece-nos apontar para o paradoxo da problemática ambiental, "incentivando" o consumo, só que, agora, de "produtos verdes".

Essa constatação vem ao encontro do que já havia sido observado em outros trabalhos que investigaram o "discurso ambiental", que demonstram que o cidadão é tratado muito mais como consumidor do que como pensador ativo e reflexivo (ORLANDI, 1996; SILVA, 2007).

Observa-se, nessas imagens, aquilo que vem sendo denominado de "pragmatismo no ambientalismo" (LOUREIRO, 2004), em que os problemas ambientais aparecem como se fossem objetivos e dados e, perante a gravidade da situação, devemos ter atitudes práticas e exitosas em curto período de tempo. É a supremacia do fazer, sem articulação com o pensar. Dessa forma, são propostas soluções que só são válidas para 
determinadas conjunturas os segmento social (daqueles que assinam e/ou compram revistas?), sendo propagadas como "salvadores do planeta". Nesse sentido, observa-se que as revistas buscam apontar padrões de comportamento a serem seguidos por aqueles que desejam "salvar o planeta", mostrando um posicionamento moral, como se a solução dependesse apenas do querer fazer e resolver, reduzindo a complexidade da questão. Foi observado, também, um chamamento à participação individual: "o que você pode fazer...". Essas propostas de "caminhos para a salvação do planeta" e de poder individual, "você pode salvar", aparecem associadas exclusivamente ao plano da ética e da consciência individual, como se elas estivessem separadas da organização social e da dinâmica que define mutuamente as dimensões em que todos vivemos (LOUREIRO, 2004), ou seja, a dimensão política.

As revistas que apresentam imagens de capa entendidas com alguns elementos da concepção crítica são aquelas dirigidas ao público constituído, em sua maioria, por professores. A Carta na Escola n. 12, ao apresentar um menino indiano (país onde os rios são considerados sagrados) no rio, pode suscitar interpretação de relação de interação ser humano-mundo natural, bem como da questão cultural do rio na Índia, representado pelo semblante de tranquilidade do menino. No entanto, também parece que busca retratar os ocidentais relacionados ao sentimento de pena, por ver uma criança nadando em um rio com lixo, o que é inaceitável para nossa cultura. Cabe ressaltar que o texto da capa é completamente desvinculado da imagem, tratando da questão dos custos do aquecimento global (pragmatismo).

A capa da Scientific American Brasil n. 19 aparece representando problemas e soluções ambientais, entendidas como responsabilidade de diversos segmentos da sociedade, e não apenas dos cidadãos comuns. Já revista Nova Escola n. 202, ao mostrar a mão (da professora?) apoiando uma outra (do aluno?), que segura uma planta, bem como a frase "ajudar os alunos a garantir o futuro do planeta”, embora representando a questão ambiental com uma planta, tem elementos que indicam a participação coletiva, e não aquela do tipo "cada um faz sua parte". Esse apelo à participação coletiva constitui um dos elementos da concepção crítica da questão ambiental.

A análise das imagens da maioria das capas revela que os meios de comunicação de massa fazem parte de um bloco hegemônico de ten- 
dências que apresentam os valores como se fossem atemporais e universais, e privilegia a concepção pragmática da problemática ambiental. Dessa forma, acreditamos que a formação integral, em qualquer área do conhecimento, não pode deixar de integrar a análise crítica da forma como a questão ambiental tem sido apresentada à sociedade.

\section{Interpretação e produção de imagens ambientais na formação docente: perspectiva para a Educação Ambiental Crítica}

Objetos simbólicos, como imagens (de livro didático, revistas, jornais, televisão, sites, esquemas, fotos...), estão presentes em praticamente todas as situações educativas, sejam elas formais ou não-formais. Martins e Gouvêa (2003) destacam que, no cotidiano escolar, as imagens circulam em diferentes suportes e em diversos contextos pedagógicos. Não obstante, as autoras ressaltam que existem poucos estudos sobre a interpretação de imagens na escola. Partimos do pressuposto de que, para o professor passar a dar atenção a esse processo de análise e interpretação de imagens, precisa ter vivenciado essa prática em sua formação.

Reigota (1999) já ressaltava que o recurso das imagens visuais é um componente que possibilita um exercício de análise crítica da influência dos meios de comunicação e do papel das imagens na sociedade contemporânea. Nesse sentido, o autor apresenta uma proposta pedagógica pioneira, realizada com base em um processo de leitura de imagens para a educação ambiental. Para o autor, a ideia central é uma "adequação à educação ambiental da proposta freireana de "leitura de mundo"' (REIGOTA, 1999, p. 122), tendo o processo dialógico como aquele que poderá contribuir para que essas leituras se ampliem. Nessa perspectiva, e buscando incorporar também outras dimensões nesse processo interpretativo de imagens na educação ambiental, foi que propusemos a atividade prática.

Acreditando que a educação ambiental participativa e emancipatória não requer a persuasão, mas, sim, a motivação para abertura para a reflexão, mostrando diversidade de olhares e mais compartilhando questões do que oferecendo respostas (TASSARA et al., 2001), e que experiências relacionadas com a dimensão axiológica, baseada em valores éticos e estéticos da questão ambiental, são uma das dimensões de complementa- 
ridade e de reciprocidade com a dimensão política da educação ambiental (CARVALHO, 2007), oferecemos a professores em formação inicial e continuada diferentes possibilidades de análise e interpretação do material imagético, buscando propiciar uma experiência de aprendizagem de caráter prático e interdisciplinar, a partir de situações reais.

A proposta tinha objetivos pedagógicos e de pesquisa. Como objetivos pedagógicos pretendia-se uma discussão crítica sobre a prevalência do discurso imagético sobre a questão ambiental e as possibilidades de uso dessas imagens para a educação ambiental escolar, um diálogo sobre as interpretações da mídia e as das professoras sobre a problemática ambiental e a problematização das diferentes dimensões, éticas, estéticas, políticas, históricas, ecológicas associadas à difusão das informações ambientais na sociedade. Buscava-se, também, discutir sobre a intencionalidade dos processos comunicativos de natureza ética, psicológica e política.

Como objetivos de pesquisa, verificava-se o processo de atribuição de significados pelas professoras em formação, as semelhanças e diferenças entre os significados que se havia atribuído às imagens, além das possibilidades de produção de imagens coletivas, incorporando componentes críticos sobre a questão ambiental, distanciado-se do senso comum.

Em importante trabalho de apresentação dos fundamentos teóricos da pedagogia crítica da educação ambiental, Tozoni-Reis (2007) destaca que a proposta educativa crítica de EA tem como ponto de partida "a idéia de que a prática social é construída e construtora de humanidade, isto é, é construída pelas relações sociais de produção da vida social, contribuindo na construção dessas mesmas relações" (TOZONI-REIS, 2007, p. 13). Nesse sentido, conforme propõe Loureiro (2006), à tradição crítica não cabe

...discutir conservação sem considerar os processos sociais que levaram ao atual quadro de esgotamento e extinção; falar em mudanças de comportamentos sem pensar como cada indivíduo vive, seu contexto e suas possibilidades concretas de fazer escolhas; defender uma forma de pensar a natureza, ignorando como cada civilização, cada sociedade e cada comunidade interagiam nela e definiam representações sobre ela; como produziam, geravam cultura e estilos de vida e como isso se da hoje. (LOUREIRO, 2006, p. 70) 
Para tanto, os produtos da indústria cultural, ao serem discutidos nos cursos de formação de professores, se apresentam como possibilidade de práxis em educação ambiental crítica, uma vez que buscamos proporcionar a discussão e a problematização de visões ecológicas difundidas pelos meios de comunicação.

O material foi utilizado em duas turmas de um curso de formação continuada de professores da educação infantil e das séries iniciais do ensino fundamental, em uma oficina com o título "Ciências Ambientais", que teve duração de um dia, e em duas turmas de um curso de formação inicial de professores de Ciências e Biologia, na disciplina Prática de Ensino.

Costa (2005) propõe as seguintes etapas metodológicas no processo de leitura de imagens no cotidiano escolar:

- tema: a escolha das imagens deve fazer parte de um processo interpretativo do professor/orientador do processo, que passa pela decisão do recorte teórico e ideológico sob o qual elas serão apresentadas;

- a forma e o momento em que a imagem será inserida no processo pedagógico;

- processo de leitura: identificar um tema em cada imagem e perceber como ele se traduz, por meio de signos visuais, numa narrativa.

Em todas as turmas, os alunos foram divididos em grupos e as capas ficaram expostas. Cada grupo recebeu uma cópia de cada capa para auxiliar na análise. O primeiro momento da aula consistiu em tentarmos "ler" as imagens e o discurso a elas associado, de forma a buscar o maior número de significados que elas traziam aos participantes. Nesse momento, solicitou-se também que se fizessem agrupamentos por semelhança. Em segundo momento, foi solicitado que, com base em recortes de revistas (gerais) e desenhos, cada grupo representasse uma imagem sobre a problemática ambiental global e, logo após, apresentasse aos demais grupos. Ou seja, a oficina contou com um momento de análise (leitura da imagem) e outro de produção.

No momento de análise, no curso de formação continuada, foi solicitado que as imagens semelhantes fossem agrupadas e que fosse realizada uma discussão no grupo sobre os sentidos que poderiam ser atribuídos a tais imagens. A partir de um roteiro de análise, deveria ser produzido um texto que representasse a leitura delas pelo grupo. Esse texto foi utilizado para o levantamento dos dados desta pesquisa. 
A maioria dos agrupamentos feitos pelos alunos foi entre imagens de catástrofe e imagens de salvação.

Algumas imagens têm a finalidade de chocar o público, causar sentimentos de terror, fazer a conscientização de uma forma bruta e chocante.

Outros agrupamentos foram propostos como: imagens reais e surreais; imagens alegres e tristes; com seres vivos e sem seres vivos. $\mathrm{Na}$ discussão, foram ressaltados vários argumentos de senso comum, como

....as imagens indicam que o ambiente está muito devastado e precisamos protegêelo.

Não importa raça, sexo ou condição social. Todos sofrerão se não houver ajuda e conscientização.

Até mesmo por uma condição social e cultural, a mulher branca tem mais consciência ambiental (...) Já o menino, que aparece nadando do meio do lixo, não só parece não ter consciência ambiental, mas também noção do perigo a que está submetido nadando no meio do lixo.

A palavra de ordem é diminuir os impactos negativos do ser humano sobre o mundo. Mas como isso é possivel? Mudando atitudes pessoais e coletivas. Pela ambição estamos desmatando florestas em busca de madeiras de lei ou para empreendimentos de agro-negócios...

É interessante observar, nesse último argumento, que as pessoas já assumem a culpa por processos dos quais elas não tiveram participação direta.

Com base nos questionamentos propostos no roteiro, que solicitava a análise atenta sobre diferentes aspectos, como presença humana, de que forma, em que contexto social, cores predominantes, posição do planeta, representação de plantas e animais, título, entre outros, estabeleceu-se um processo de atribuição de sentidos e de reflexão crítica das imagens, conforme destacamos nos trechos a seguir, referentes aos aspectos sociais observados nas capas:

É possivel inferir ou identificar a raça, sexo, condição social, em especial do garoto negro nadando no lixo (...). Nas outras revistas aparecem famílias de pessoas brancas de classe média alta. O que se pode observar é que só pessoas brancas/ricas são salvadoras e os negros pobres são os 'coitados' que sempre necessitam de ajuda. 
A capa onde mostra um indiano tomando banho no Rio Ghandi, nos passa a informação de que é preciso preservar para que não sejamos prejudicados futuramente. Embora no que se refere a Índia tem relação com a cultura do país.

As imagens têm um apelo para o lado emotivo do publico, querem sensibilizar os leitores, utilizando das camadas populares (menino negro) e dos animais do ártico.

Podemos perceber que as imagens enfatizam a raça branca com dados positivos sobre a questão ambiental e a raça negra está associada a problemas.

Observou-se a interpretação crítica dos grupos no sentido de perceber a escolha de "modelos" para representar salvação e necessidade de ajuda, bem como a identificação de características culturais nas imagens. O que percebemos, e que chamou muito a atenção das professoras em formação, foram as propostas de "salvação" da revista Veja n. 2031 (sapatos com sola de pneu, calça de algodão feita a mão, trabalhar de bicicleta...). Foi discutido o modelo proposto/imposto de participação no salvamento do planeta e a necessidade de buscar formas pertinentes de ação individual e coletiva frente à realidade de cada um. Surgiram comentários do tipo:

Eu não posso comprar, com o meu salário de professora, os alimentos orgânicos e muito menos uma calça de algodão feita a mão...

Se ela trabalhasse tão longe quanto eu, queria ver se ia de bicicleta...

Quanto à análise das imagens do globo terrestre, foi observada pelos grupos a centralidade do continente americano, à qual foram atribuídas diferentes interpretações:

O continente que aparece ao centro é sempre o americano, em especial o norte-americano, porque os Estados Unidos possuem o maior marketing do planeta e desejam, a todo custo, manter sua boa e correta imagem de investidores e salvadores do mundo.

Normalmente, é enfatizado o continente norte-americano, o que se deve ao fato dele ser considerado o maior polvidor do planeta.

Talvez na intenção de mostrar que sendo um continente com paises do 'Primeiro Mundo', embora com tanta tecnologia e maior poder aquisitivo, estes são também grande ou até os maiores responsáveis por parte dos desequilíbrios ecológicos, tanto em parte do consumo abusivo, quanto em parte de não fazer tanto quanto poderiam. 
Essa discussão buscou possibilitar que as professoras conseguissem identificar que havia um discurso hegemônico por trás da maioria das imagens e que, muitas vezes, ele está desvinculado de um contexto social e político. Lembramos os grupos de sua participação importantíssima enquanto educadoras não na indicação de comportamentos, mas no sentido de auxiliar os educandos a encontrarem suas reais possibilidades de participação.

Na parte de produção de imagens, os(as) professores(as) revelaram grandes dificuldades e, embora alguns grupos tenham incorporado elementos mais críticos, a maioria não conseguiu sair do senso comum, não conseguindo produzir imagens que identificassem a discussão ocorrida no grupo, quando da análise das capas. A maior parte das imagens produzidas continha desenhos de árvores e argumentos de salvação ou desenhos do planeta Terra pegando fogo, derretendo, sumindo, chorando, pedindo ajuda, entre outros, que foram bastante frequentes, como argumentos do tipo "vamos salvar agora senão o planeta vai desaparecer". As pessoas passam anos e anos em contato com o mesmo tipo de representação e acabam a incorporando, não conseguindo se distanciar do que representam, o que confirma a hipótese de Reigota (1999), segundo a qual as imagens originam e difundem representações sociais sobre a questão ambiental. As mesmas imagens que criticam são reproduzidas em suas produções.

Percebeu-se, tanto nos argumentos apresentados na análise quanto nos resultados das produções, dificuldade em trabalhar com imagens, o que revela a necessidade de o trabalho com leitura e produção de imagens ser mais presente, não só nos cursos de formação de professores, mas também na escola de educação infantil, fundamental e média.

\section{Considerações finais}

Esta pesquisa procurou identificar nas imagens da questão ambiental de capas de revista de grande circulação, a partir de categorias definidas, o sentido de sua produção e utilização. Também foram investigados os sentidos produzidos por professores em formação, com base em um processo dinâmico de leitura (atribuição de sentidos) das capas e de produção de novas imagens. 
A análise das imagens da maioria das capas revela que os meios de comunicação de massa fazem parte de um bloco hegemônico de tendências que privilegiam uma concepção pragmática da problemática ambiental, tratando o cidadão como consumidor.

Os processos interpretativos realizados por professores em formação revelam uma diversidade de formas de envolvimento com as imagens, nos níveis cognitivo, afetivo e crítico. Por meio das discussões coletivas, puderam ser questionadas algumas visões dos meios de comunicação de massa sobre a questão ambiental, que muitas vezes são assimiladas de forma acrítica e inconsciente, sendo, na verdade, uma fonte de incentivo ao consumo.

Carvalho (2007) identifica que questões importantes ultrapassam o aspecto meramente técnico do debate ecológico e nos colocam perante aos aspectos político ideológicos. Tais aspectos também puderam ser discutidos a partir do material de análise, propiciando a interpretação de dimensões éticas e políticas relacionadas à questão. $\mathrm{Na}$ condução da proposta, observou-se que a leitura de imagens implicou a decodificação de alguns interesses nela presentes e se apresentou com possibilidade de outras leituras e ações.

As reflexões realizadas pelos(as) professores(as) em formação, a partir da mediação entre as imagens ambientais produzidas pela mídia impressa de grande circulação e seus próprios saberes referentes à questão, estão no caminho de uma pedagogia crítica da educação ambiental, pois, conforme reflexão feita por Tozoni-Reis (2007), "a contextualização histórica e social dos saberes é elemento fundamental dos processos educativos", nessa perspectiva.

Também ressaltamos que não existem resultados rápidos em trabalhos como este, mas há caminhos de um processo que busca auxiliar na formação de professores para que sejam capazes de fazer relações entre diferentes contextos e discursos e incorporar atividades mais reflexivas em seu cotidiano escolar, questionando criticamente o processo de produção e massificação da mídia frente à questão ambiental.

Nesse sentido, o processo interpretativo de imagens na escola pode possibilitar uma ferramenta a mais na construção da cidadania, formando observadores menos ingênuos e mais críticos diante das imagens com que se deparam na vida cotidiana. 


\section{Notas}

${ }^{1}$ O relatório representa o resultado de cinco anos de estudos realizados por cientistas de vários países. O IPCC foi criado em 1988, a partir da Organização Meteorológica Mundial (WMO) e do Programa das Nações Unidas para o Meio Ambiente (PNUMA) para organizar uma base de dados com informações técnicas, científicas e socioeconômicas sobre o fenômeno do aquecimento global (LUCKMAN, 2007).

${ }^{2}$ Esta edição, embora tenha sido incluída em nossa análise, não foi utilizada no trabalho com os professores, pois foi lançada posteriormente.

\section{Referências bibliográficas}

ANDRADE, T. Ecológicas manhãs de sábado: o espetáculo da natureza na televisão brasileira. São Paulo: Annablume: FAPESP, 2003.

BARDIN, L. Análise de conteúdo. Lisboa: Edições 70, 1977.

BRASIL./ Ministério da Ciência e Tecnologia. Percepscão Pública da Ciência e Tecnologia. Brasília: MCT, 2007. Disponível em <www.mct.gov.br>. Acesso em: 28/10/2007.

BRUZZO, C. Biologia: Educação e imagens. Educ. Soc. Campinas, v. 25, n. 89, p. 13591378, set./dez. 2004. Disponível em <www.cedes.unicamp.br>. Acessado em: 12/12/2007.

CARVALHO, L. M. de. A temática ambiental e o processo educativo: dimensões e abordagens. In: CINQUETTI, H. S.; LOGAREZZI, A. Consumo e resíduos: fundamentos para o trabalho educativo. São Carlos: Editora da UFSCar, 2007. p. 19-41.

COSTA, C. Educaşão, imagens e mídias. São Paulo: Cortez, 2005. (Coleção Aprender e Ensinar com textos v. 12)

FLORENTINO, H.F. Uma análise das concepções sobre ciência, biodiversidade e desenvolvimento sustentável presentes no discurso de um programa televisivo. 125f. Dissertação (Mestrado em Educação). Faculdade de Educação, Universidade de São Paulo, São Paulo, 2007.

GRÜN, M. Ética e Educação Ambiental: a conexão necessária. Campinas, SP: Papirus, 1996. (Coleção Magistério: Formação e trabalho Pedagógico)

GUIDO, L. F. E. Educação, televisão e natureza: uma análise do Repórter ECO. Trabalho apresentado no GT 22. Anais da 29ª Reunião anual da Associação Nacional de Pósgraduação em Educação. Caxambu, 15 a 18 de outubro de 2006.

LOUREIRO, C. F. B. Trajetória e fundamentos da Educação Ambiental. São Paulo: Cortez, 2004.

LOUREIRO, C. F. B. Educação ambiental e “teorias críticas”. In: GUIMARÃES, M. (Org.) Caminhos da educação ambiental: da forma à ação. Campinas, SP: Papirus, 2006. p. 5186.

LOUREIRO, R.; FONTE, S. S. D. Indústria cultural e educação em "tempos pós-modernos". Campinas, SP: Papirus, 2003.

LUCKMAN, A. P. Educação, jornalismo e meio ambiente: leituras sobre a crise ecológica no contexto do aquecimento global. Anais da $30^{a}$ Reunião Anual da ANPED, GT $16-$ Comunicação e Educação, outubro de 2007.

MARTINS, I.; GOUVÊA, G. Práticas de leituras de imagens em livros didáticos de Ciências. Anais do II Encontro Internacional Redes de Conbecimento, Rio de Janeiro, 2003. 
ORLANDI, E. P. O discurso da Educação Ambiental. In: TRAJBER, R. \& MANZOCHI, L. H. Avaliando a Educação Ambiental no Brasil: materiais impressos. São Paulo: Gaia, 1996. p. 37-47.

RAMOS, L. F. A. O desafio da comunicação ambiental: um estudo das propagandas das ONGs na TV. Tese (Doutorado em Comunicação). Escola de Comunicação e Artes da USP. São Paulo, 2002, 290 p.

REIGOTA, M. A floresta e a escola: por uma educação ambiental pós-moderna. São Paulo, Cortez, 1999.

SILVA, H. C. Lendo imagens na educação científica: construção e realidade. Pro-Posições - Faculdade de Educação da UNICAMP. Campinas, SP, v. 17, n. 1 (49), p. 71-83, jan./abr. 2006.

SILVA, R. L. F. O meio ambiente por trás da tela - estudo das concepções de educação ambiental dos filmes da TV Escola. Tese (Doutorado em Educação). Faculdade de Educação da USP, São Paulo, 2007.

TASSARA, E. T. et. al. Propostas para a instrumentalização de uma educação ambiental transformadora. In: COSTA, L. B. \& TRAJBER, R. (Orgs.) Avaliando a Educação Ambiental no Brasil: materiais audiovisuais. São Paulo: Peirópolis: Instituto Ecoar para Cidadania, 2001. p. 29-51.

TOZONI-REIS, M. F. C. Fundamentos teóricos para uma pedagogia crítica da Educação Ambiental. Anais da 30 Reunião Anual da ANPED, GT 22 - Educação Ambiental, outubro de 2007.

\section{Endereço para correspondência: Universidade Federal do $A B C$ Centro de Ciências Naturais e Humanas Rua Santa Adélia, 166 Bairro Bangu 09210-170 \\ Santo André - SP}

Data de recebimento: $30 / 03 / 2009$

Data de aprovação: 12/04/2010 